\title{
PENGARUH STRATEGI PEMBELAJARAN MIND MAP DAN EKSPOSITORI DENGAN GAYA BELAJAR TERHADAP HASIL BELAJAR TEKNOLOGI PERKANTORAN
}

\author{
Darmauli \\ Sekolah Menengah Kejuruan Negeri 7 Medan \\ darmauli.pjt@gmail.com
}

\begin{abstract}
Abstrak: Tujuan penelitian adalah Perbedaan hasil belajar Teknologi Perkantoran antara siswa yang diajar dengan strategi pembelajaran Mind Map dan hasil belajar siswa yang diajar dengan strategi pembelajaran ekspositori, Perbedaan hasil belajar Teknologi Perkantoran antara siswa yang memiliki gaya belajar visual dengan yang memiliki gaya belajar kinestetik, dan interaksi antara strategi pembelajaran dan gaya belajar terhadap hasil belajar Teknologi Perkantoran. Populasi penelitian ini adalah seluruh siswa kelas X, berjumlah 145 orang yang berasal dari 4 kelas. Teknik penarikan sampel dilakukan dengan cluster random sampling. Metode penelitian yang menggunakan metode quasi eksperimen dengan desain penelitian faktorial $2 \times 2$. Teknik analisis data menggunakan ANAVA dua jalur pada taraf signifikansi $\alpha=0,05$. Temuan penelitian menunjukkan bahwa: hasil belajar Teknologi Perkantoran siswa yang diajar dengan strategi pembelajaran Mind Map, lebih tinggi dari pada hasil belajar siswa yang diajar dengan strategi pembelajaran ekspositori, hasil belajar Teknologi Perkantoran siswa yang memiliki gaya belajar Kinestetik lebih tinggi daripada hasil belajar siswa yang memiliki gaya belajar Visual, terdapat interaksi antara strategi pembelajaran dan gaya belajar terhadap hasil belajar Teknologi Perkantoran. Perhitungan uji lanjut dengan uji Scheffe menunjukkan hasil belajar Teknologi Perkantoran siswa yang memiliki gaya belajar kinestetik lebih tinggi bila diajar dengan strategi pembelajaran Mind Map, sedangkan hasil belajar Teknologi Perkantoran siswa yang memiliki gaya belajar visual lebih tinggi bila diajar dengan strategi pembelajaran ekspositori.
\end{abstract}

Kata Kunci:strategi pembelajaran, mind map, ekspositori, teknologi perkantoran

\begin{abstract}
The research objectives are: differences in office technology learning outcomes between students taught with mind map learning strategies and student learning outcomes taught with expository learning strategies, differences in office technology learning outcomes between students who have visual learning styles with which has a kinesthetic learning style, and the interaction between learning strategies and learning styles on the learning outcomes of office technology. The population of this study was all students of class X, totaling 145 people from 4 classes. The sampling technique is done by cluster random sampling. The research method that uses a quasi-experimental method with a $2 \times 2$ factorial research design. Data analysis techniques using two-way ANOVA at a significance level $\alpha=0.05$. The research findings show that: the learning outcomes of office technology students taught with mind map learning strategies are higher than the learning outcomes of students taught with expository learning strategies, learning outcomes of office technology students who have higher kinesthetic learning styles rather than student learning outcomes that have a visual learning style, there is an interaction between learning strategies and learning styles on learning outcomes of office technology. The calculation of further tests with the scheffe test shows the learning outcomes of office technology students who have higher kinesthetic learning styles when taught with mind map learning strategies, whereas office technology learning outcomes of students who have higher visual learning styles when taught with expository learning strategies.
\end{abstract}

Keywords: learning strategies, mind maps, expository, office technology

\section{PENDAHULUAN}

Pendidikan adalah suatu sistem yang didalamnya terdapat proses pembelajaran dimana siswa mampu mengembangkan potensi yang dimilikinya. Sejalan dengan adanya hal itu menurut Undang-undang Nomor 20 Tahun 2003 tentang Sistem Pendidikan Nasional menyebutkan bahwa yang dimaksud dengan pendidikan adalah usaha sadar dan terencana untuk mewujudkan suasana belajar dan proses pembelajaran agar siswa secara aktif mengembangkan potensi dirinya untuk memiliki kekuatan spiritual keagamaan, pengendalian diri, kepribadian, kecerdasan, akhlak mulia, serta keterampilan yang diperlukan dirinya, masyarakat, bangsa dan Negara. Dengan demikian guru mempunyai kewajiban untuk mendidik dan mengajarkan 
konsep pembelajaran agar lebih tertanam pada siswa. Guru, siswa, model pembelajaran, media pembelajaran, dan proses belajar mengajar merupakan faktor tercapainya tujuan pembelajaran.

Dalam hal ini, tentu diperlukan media dan model pembelajaran yang sesuai dengan perkembangan jaman. Media dan model pembelajaran dipilih agar siswa dapat lebih tertarik dan berminat dengan proses pembelajaran serta dapat lebih membantu siswa dalam memahami materi pelajaran sedangkan media yang dipersiapkan harus terprogram dengan baik, karena perkembangan dari perubahan teknologi informasi dapat mempengaruhi semuanya. Perubahan teknologi memiliki beberapa dampak dalam bidang pendidikan diantaranya menuntut seseorang untuk memiliki ketrampilan baru, dapat mempersiapkan lulusan sesuai perkembangan teknologi yang terjadi, penggunaan media, komunikasi, transformasi dan bioteknologi dalam mendukung kegiatan dibidang pendidikanPengaruh teknologi terhadap lembaga pendidikan adalah pada penggunaan media, komunikasi, transformasi dan revolusi bioteknologi.

\section{Hakikat Belajar Teknologi Perkantoran}

Teknologi Perkantoran merupakan salah satu mata pelajaran produktif pada kurikulum 2013 yang mempelajari tentang pengoperasian perangkat lunak pengolah kata, pengolah angka, aplikasi presentasi, teleconference dan blog untuk membantu pekerjaan kantor. Dalam hal ini peneliti melakukan penelitian pada mata pelajaran Teknologi Perkantoran dengan materi pengoperasian aplikasi presentasi. Secara keseluruhan materi mata pelajaran tersebut hampir $90 \%$ berupa praktek yang mana disampaikan guru dengan metode ceramah dengan memberi contoh namun terlalu cepat dalam menjelaskannya, hal itu menyebabkan siswa tertinggal materi yang telah dijelaskan. Menyikapi permasalahan yang berkaitan dengan pembelajaran, maka perlu upaya perbaikan dan inovasi dalam kegiatan pembelajaran. Salah satu alternative yang biasa dipakai adalah guru melakukan perbaikan dalam proses pembelajarannya, disini guru sebagai perancang dan organisator sehingga siswa memperoleh kesempatan untuk memahami dan mendalami materi ajar dalam proses kegiatan belajar tersebut, peneliti akan mencoba menerapkan stretagi pembelajaran mind map.

Gagne (1984) mengatakan belajar adalah suatu perubahan watak (disposition) dan kemampuan (capability) manusia yang berlangsung selama suatu jangka waktu dan tak sekedar menganggapnya proses pertumbuhan. Selanjutnya Gagne mengatakan belajar terjadi apabila suatu situasi stimulus bersama dengan isi ingatan mempengaruhi siswa sedemikian rupa sehingga perbuatan (performance) berubah dari waktu ke waktu selama ia mengalami situasi.

Berkaitan dengan hubungan antara belajar dan pengalaman, Djamariah dan Zain (2002) mengatakan belajar adalah proses perubahan perilaku berkat pengalaman dan latihan. Menurut Achmadi (1993), belajar adalah menambah dan mengumpulkan sejumlah pengetahuan. Dari kedua pendapat dapat dijelaskan bahwa tujuan kegiatan belajar adalah perubahan tingkah laku, baik yang menyangkut pengetahuan, keterampilan maupun sikap, bahkan meliputi segenap aspek organisasi atau pribadi. Sejalan dengan itu, Tirta dan Sula (1994) mengatakan bahwa belajar diartikan sebagai aktivitas pengembangan diri melalui pengalaman, bertumpu pada kemampuan dari siswa di bawah bimbingan guru. Burner dalam Slameto (1993) mengatakan bahwa belajar yang terbaik haruslah merupakan proses berpikir. Berpikir pada hakekatnya merupakan proses kognitif, sehingga manusia dapat membedakan, memilih dan menentukan objek, serta kemampuan untuk mengkontruksi kembali informasi, keterampilan dan pengetahuan yang telah diterima.

\section{Hakikat Strategi Mind Map}

Mind Map menurut Sutanto (2008:16) adalah suatu teknik grafis yang memungkinkan kita untuk mengeksplorasi seluruh kemampuan otak kita untuk keperluan berfikir dan belajar.

Menurut Sutanto (2008:16) Otak manusia secara fungsional dibagi ke dalam dua bagian yaitu otak kanan dan otak kiri. Otak kiri akan berkaitan dengan kata, angka, analisa, logika, urutan, hitungan dan detil. Sedangkan otak kanan berkaitan dengan gambar, warna, irama, gestalt dimensi, imajinasi, dan melamun.

Sedangkan menurut Sutanto (2008:2): "Whole Brain Thinking adalah suatu terobosan cara berpikir dengan memanfaatkan dua belahan otak secara sinergis. Mind mapping atau pemetaan pikiran merupakan salah satu 
teknik mencatat tinggi." Informasi berupa materi pelajaran yang diterima siswa dapat diingat dengan bantuan catatan. Peta pikiran merupakan bentuk catatan yang tidak monoton karena Mind mapping memadukan fungsi kerja otak secara bersamaan dan saling berkaitan satu sama lain. Sehingga akan terjadi keseimbangan kerja kedua belahan otak. Otak dapat menerima informasi berupa gambar, simbol, citra, musik dan lain-lain yang berhubungan dengan fungsi kerja otak kanan.

\section{Strategi Pembelajaran Ekspositori}

Strategi pembelajaran Ekspositori menekankan kepada proses bertutur. Aliran psikologi belajar yang sangat mempengaruhi strategi pembelajaran Ekspositori ini adalah aliran belajar behavioristik. Aliran belajar behavioristik ini lebih menekankan kepada pemahaman bahwa perilaku manusia pada dasarnya keterkaitan antara stimulus dan respons.

Sanjaya (2009:179) mengemukakan bahwa strategi pembelajaran Ekspositori adalah strategi pembelajaran yang menekankan kepada proses penyampaian materi secara verbal dari seorang guru kepada sekelompok siswa dengan maksud agar siswa dapat menguasai materi pelajaran secara optimal.

Killen dalam Sanjaya (2009) menamakan strategi Ekspositori ini dengan istilah strategi pembelajaran langsung (direct instruction). Oleh karena strategi ekspositori lebih menekankan kepada proses bertutur, maka sering juga dinamakan dengan istilah strategi "chalk and talk".

Terdapat beberapa karakteristik pada strategi pembelajaran Ekspositori (Sanjaya, 2009:179) yaitu seperti berikut ini : (1) Strategi Ekspositori dilakukan dengan cara menyampaikan materi pelajaran secara verbal, artinya bertutur lisan merupakan alat utama dalam melakukan strategi ini, oleh karena itu orang sering mengidentikkannya dengan ceramah. (2) Biasanya materi pelajaran yang disampaikan adalah materi pelajaran yang sudah jadi, seperti data atau fakta, konsepkonsep tertentu yang sudah dihafal sehingga tidak menuntut siswa untuk berfikir ulang. (3) Tujuan utama pembelajaran adalah penguasaan materi pelajaran itu sendiri. Artinya, setelah proses pembelajaran berakhir siswa diharapkan dapat memahaminya dengan benar dengan cara dapat menggungkapkan kembali materi yang telah diuraikan.
Strategi pembelajaran Ekspositori merupakan bentuk dari pendekatan pembelajaran yang berorientasi kepada guru (teacher oriented). Dikatakan demikian, sebab dalam strategi ini guru memegang peran yang sangat dominan. Fokus utama strategi ini adalah kemampuan akademik (academic achievement) siswa. Metode pembelajaran dengan kuliah merupakan bentuk Strategi Ekspositori.

Strategi pembelajaran Ekspositori akan lebih efektif manakala: (1) Guru akan menyampaikan bahan-bahan baru serta kaitannya dengan yang akan dan harus dipelajari siswa (overview). Oleh sebab itu materi yang disampaikan adalah materi-materi dasar seperti konsep-konsep tertentu, prosedur atau rangkaian aktivitas, dan lain sebagainya. (2) Jika guru menginginkan agar siswa mempunyai gaya model intelektual tertentu. (3) Jika bahan pelajaran yang akan diajarkan cocok untuk dipresentasikan, misalnya materi pelajaran hasil penelitian berupa data-data khusus. (4) Jika ingin membangkitkan keingintahuan siswa tentang topik tertentu. 5) Guru menginginkan untuk mendemonstrasikan suatu teknik atau prosedur tertentu untuk kegiatan praktik. (6) Apabila seluruh siswa memiliki tingkat kesulitan yang sama sehingga guru perlu menjelaskan untuk seluruh siswa. (7) Apabila guru akan mengajar pada sekelompok siswa yang rata-rata memiliki kemampuan rendah (low achieving students). (8) Jika lingkungan tidak mendukung untuk menggunakan strategi yang berpusat pada siswa. (9) Jika guru tidak memiliki waktu yang cukup untuk menggunakan pendekatan yang berpusat pada siswa.

Dalam penggunaan strategi pembelajaran ekspositori Sanjaya (2009: 181) terdapat beberapa prinsip yang harus diperhatikan oleh setiap guru. Setiap prinsip tersebut dijelaskan sebagai berikut : (1) Berorientasi pada Tujuan, penyampaian materi merupakan ciri utama dalam strategi pembelajaran Ekspositori melalui metode ceramah, namun tidak berarti proses penyampaian materi tanpa tujuan pembelajaran. Hal itulah yang menjadi pertimbangan utama dalam penggunaan strategi ini. Sebelum strategi ini diterapkan terlebih dahulu, guru harus merumuskan tujuan pembelajaran secara jelas dan terukur. Seperti pada umumnya tujuan pembelajaran harus dirumuskan dalam bentuk tingkah laku yang dapat diukur atau berorientasi pada kompetensi yang harus dicapai siswa. 
Strategi pembelajaran Ekspositori tidak mungkin dapat mengejar tujuan kemampuan berfikir tingkat tinggi, misalnya kemampuan untuk menganalisis, mensintesis, atau mungkin mengevaluasi sesuatu, namun tidak berarti tujuan kemampuan berfikir taraf rendah tidak perlu dirumuskan, justru tujuan itulah yang harus dijadikan ukuran dalam menggunakan strategi Ekspositori. (2) Prinsip Komunikasi, proses pembelajaran dapat dikatakan sebagai proses komunikasi yang menunjuk pada proses penyampaian pesan dari seseorang (sumber pesan) kepada seseorang atau kelompok orang (penerima pesan). Pesan yang ingin disampaikan dalam hal ini adalah materi pelajaran yang diorganisir dan disusun sesuai dengan tujuan tertentu yang ingin dicapai. Dalam proses komunikasi guru berfungsi sebagai sumber pesan. Sistem komunikasi dikatakan tidak efektif jika penerima pesan tidak dapat menangkap setiap pesan yang disampaikan. Kesulitan menangkap pesan itu dapat terjadi oleh berbagai gangguan (noise) yang dapat menghambat kelancaran proses komunikasi. Akibat gangguan (noise) tersebut memungkinkan penerima pesan (siswa) tidak memahami atau tidak dapat menerima sama sekali pesan yang ingin disampaikan. Sebagai suatu strategi pembelajaran yang menekankan pada proses penyampaian, maka prinsip komunikasi merupakan prinsip yang sangat penting untuk diperhatikan. Artinya, bagaimana upaya yang bisa dilakukan agar setiap guru dapat menghilangkan setiap gangguan (noise) yang bisa mengganggu proses komunikasi. (3) Prinsip Kesiapan, dalam teori belajar koneksionisme, "kesiapan" merupakan salah satu hukum belajar. Inti dari hukum belajar adalah bahwa setiap individu akan merespons dengan cepat dari setiap stimulus manakala dalam dirinya sudah memiliki kesiapan, sebaliknya, tidak mungkin setiap individu akan merespons setiap stimulus yang muncul manakala dalam dirinya belum memiliki kesiapan. Dapat ditarik kesimpulan dari hukum belajar ini adalah agar siswa dapat menerima informasi sebagai stimulus yang kita berikan, terlebih dahulu kita harus memposisikan mereka dalam keadaan siap baik secara fisik maupun psikis untuk menerima pelajaran, sebaiknya pelajaran tersebut jangan disajikan terlebih dahulu manakala siswa belum siap untuk menerimanya. (4). Prinsip berkelanjutan, prinsip ini menjelaskan bahwa strategi pembelajaran Ekspositori harus dapat mendorong siswa untuk mau mempelajari materi pelajaran lebih lanjut. Pembelajaran Ekspositori yang berhasil jika melalui proses penyampaian dapat membawa siswa pada situasi ketidakseimbangan (disequilibrium), sehingga mendorong mereka untuk mencari dan menemukan atau menambah wawasan melalui proses belajar mandiri.

\section{Hakikat Gaya Belajar}

Pada tahun 1983 Howard Gardner dalam bukunya The Theory of Multiple Intelegence, mengusulkan tujuh macam komponen kecerdasan, yang disebutnya dengan Multiple Intelegence (Intelegensi Ganda). Intelegensi ganda meliputi: (1) kecerdasan linguistic-verbal dan (2) kecerdasan logikomatematik yang sudah dikenal sebelumnya, ia menambahkan dengan komponen kecerdasan lainnya yaitu (3) kecerdasan spasial-visual, (4) kecerdasan ritmik-musik, (5) kecerdasan kinestetik, (6) kecerdasan interpersonal, (7) kecerdasan intrapersonal. Sekarang tujuh kecerdasan tersebut di atas sudah bertambah lagi dengan satu komponen kecerdasan yang lain, yaitu (8) kecerdasan naturalis.

Kemudian De Porter (2008: 110) mengatakan gaya belajar merupakan cara yang cenderung dipilih seseorang untuk menerima informasi dari lingkungan dan memproses informasi tersebut. Dalam hal belajar, masingmasing individu memiliki kelebihan dan kekurangan dalam menyerap pelajaran yang diberikan. Oleh karena itu dalam dunia pendidikan dikenal berbagai metode yang dapat dipergunakan guru untuk dapat memenuhi tuntutan perbedaan individu tersebut. Guru membutuhkan rancangan desain pembelajaran untuk menjembatani hubungan antara siswa dengan guru sesuai dengan gaya belajarnya.

Olivia (2008 2) mengatakan bahwa tidak ada gaya belajar yang lebih baik dari yang lain, karena ketiga gaya belajar ini dimiliki oleh setiap orang. Hanya saja ada salah satu gaya belajar yang lebih dominan pada diri kita. Jadi, bila seseorang belajar sesuai dengan gaya belajarnya yang dominan, pelajaran akan lebih mudah diterima dan kemungkinan suksesnya juga lebih tinggi.

Menurut DePorter (2007: 165) ada beberapa gaya belajar lainnya yang bisa dipilih untuk belajar secara efektif. Beberapa gaya belajar yang mungkin terdapat pada anak didik yakni gaya belajar Auditorial, gaya belajar Kinestetik, dan gaya belajar Visual. 
Mengamati tingkah laku anak seharihari, terutama saat mereka bermain, adalah cara yang paling efektif mengamati kecenderungan gaya belajar anak. Sesuai dengan karakteristik pembelajaran menggambar teknik yang cenderung pada ranah psikomotorik, gaya belajar yang akan diteliti akan dibatasi hanya pada gaya belajar visual dan kinestetik.

\section{METODE}

Penelitian in dilaksanakan di SMK Negeri 7. Teknik pengambilan sampel dilakukan dengan teknik cluster random sampling, selanjutnya melalui pengundian kelas $\mathrm{X}$ Administrasi Perkantoran sebagai kelas yang diberi perlakuan dengan strategi pembelajaran Mind Map (kelas eksprimen) Administrasi Perkantoran terpilih sebagai kelas yang diberi perlakuan dengan strategi pembelajaran ekspositori (kelas kontrol). Sebelum dilakukan eksperimen, kedua kelas sampel terlebih dahulu diberi tes untuk mengetahui gaya belajar siswa. Gaya belajar dikategorikan atas gaya belajar kinestetik dan gaya belajar visual.

Penelitian ini menggunakan metode eksperimental semu (quasi-experimental design) dengan melakukan eksperimen di dalam kelas yang sudah tersedia sebagaimana adanya, tanpa melakukan perubahan situasi kelas dan jadwal pembelajaran (kelas yang intaks). Perlakuan dilaksanakan pada pembelajaran Mengambar teknik dengan menggunakan strategi pembelajaran Mind Map yang dibandingkan dengan strategi pembelajaran ekspositori dan dilaksanakan pada kelas perlakuan yang telah ditetapkan. Pada masingmasing kelas terdapat siswa yang memiliki gaya belajar kinestetik dan gaya belajar visual berdasarkan hasil analisis skor tes gaya belajar menurut De Porter (2008) yang telah baku dan disusun dengan menggunakan indikatorindikator yang telah standar. Guru yang ditetapkan untuk melakukan pembelajaran dengan strategi pembelajaran berbasis masalah maupun ekspositori diberikan petunjuk khusus mengenai cara dan langkah-langkah dalam penyajian materi pelajaran.

Desain penelitian yang digunakan adalah desain faktorial $2 \times 2$, seperti terlihat pada Tabel 1. yang mengelompokkan strategi Mind Map dengan strategi pembelajaran ekspositori terhadap gaya belajar visual dan gaya belajar kinestetik.
Tabel 1. Desain Faktorial $2 \times 2$

\begin{tabular}{|l|c|c|}
\hline \multirow{2}{*}{$\begin{array}{c}\text { Gaya belajar } \\
(\mathrm{B})\end{array}$} & \multicolumn{2}{|c|}{ Strategi Pembelajaran $(\mathrm{A})$} \\
\cline { 2 - 3 } & $\begin{array}{c}\text { Mind } \\
\text { Map }\left(\mathrm{A}_{1}\right)\end{array}$ & $\begin{array}{c}\text { Ekspositori } \\
\left(\mathrm{A}_{2}\right)\end{array}$ \\
\hline Kinestetik $\left(\mathrm{B}_{1}\right)$ & $\mathrm{A}_{1} \mathrm{~B}_{1}$ & $\mathrm{~A}_{2} \mathrm{~B}_{1}$ \\
\hline Visual $\left(\mathrm{B}_{2}\right)$ & $\mathrm{A}_{1} \mathrm{~B}_{2}$ & $\mathrm{~A}_{2} \mathrm{~B}_{2}$ \\
\hline
\end{tabular}

Keterangan :

$\mathrm{A}=$ Strategi pembelajaran

$\mathrm{B}=$ Gaya belajar

$\mathrm{A}_{1} \quad=$ Strategi pembelajaran Mind Map

$\mathrm{A}_{2}=$ Strategi pembelajaran ekspositori

$\mathrm{B}_{1}=$ Gaya belajar kinestetik

$\mathrm{B}_{2}=$ Gaya belajar visual

$\mathrm{A}_{1} \mathrm{~B}_{1}=$ Hasil belajar Teknologi

Perkantoran siswa yang diajar dengan menggunakan strategi Mind Map pada siswa dengan gaya belajar kinestetik

$\mathrm{A}_{1} \mathrm{~B}_{2}=$ Hasil belajar Teknologi

Perkantoran siswa yang diajar dengan menggunakan strategi Mind Map pada siswa dengan gaya belajar visual.

$\mathrm{A}_{2} \mathrm{~B}_{1}=$ Hasil belajar Teknologi Perkantoran siswa yang diajar dengan menggunakan strategi pembelajaran ekspositori pada siswa dengan gaya belajar kinestetik.

$\mathrm{A}_{2} \mathrm{~B}_{2}=$ Hasil belajar Teknologi Perkantoran siswa yang diajar dengan menggunakan strategi pembelajaran ekspositori pada siswa dengan gaya belajar visual.

\section{Teknik Analisis Data}

Teknik analisis data dalam penelitian ini menggunakan analisis deskriptif dan analisis inferensial. Teknik analisis deskriptif dimaksudkan untuk mendeskripsikan data penelitian meliputi mean, median, standard deviasi dan kecenderungan data.

Data yang telah diperoleh selanjutnya disajikan dalam bentuk tabel distribusi frekuensi dan histogram. Teknik analisis inferensial digunakan untuk menguji hipotesis penelitian dengan menggunakan teknik analisis varians (ANAVA) dua jalur. Untuk menggunakan ANAVA dua jalur perlu dipenuhi beberapa syarat yaitu: (1) data yang 
digunakan harus berdistribusi normal, untuk menguji normalitas data digunakan uji Liliefors, dan (2) data harus memiliki varians populasi homogen, untuk menguji homogenitas varians digunakan uji F (Fisher) dan

Rumusan hipotesis statistik dalam penelitian ini adalah sebagai berikut:

a. Hipotesis pertama :

$$
\begin{aligned}
& \text { Ho }: \mu_{A 1} \leq \mu_{A 2} \\
& \text { H1 }: \mu_{A 1}>\mu_{A 2}
\end{aligned}
$$

b. Hipotesis kedua :

$$
\begin{aligned}
& \text { Ho }: \mu_{B 1} \leq \mu_{B 2} \\
& \text { H1 }: \mu_{B 1}>\mu_{B 2}
\end{aligned}
$$

c. Hipotesis ketiga :

$$
\begin{aligned}
& \mathrm{Ho}: \mathrm{A} \times \mathrm{B}=0 \\
& \mathrm{H} 1: \mathrm{A} \times \mathrm{B} \neq 0
\end{aligned}
$$

Keterangan :

$$
\begin{aligned}
& \mathrm{A}=\text { Strategi pembelajaran } \\
& \mathrm{B}=\text { Gaya belajar } \\
& \mathrm{A}_{1}=\text { Strategi pembelajaran Mind Map } \\
& \mathrm{A}_{2}=\text { Strategi pembelajaran ekspositori } \\
& \mathrm{B}_{1}=\text { Gaya belajar kinestetik } \\
& \mathrm{B}_{2}=\text { Gaya belajar visual }
\end{aligned}
$$

$$
\mu_{A 1}=\text { Hasil belajar Teknologi Perkantoran }
$$
siswa yang memperoleh pembelajaran dengan strategi Mind Map

$\mu_{A 2}=$ Hasil belajar Teknologi Perkantoran siswa yang memperoleh pembelajaran dengan strategi

pembelajaran ekspositori

$\mu_{B 1}=$ Hasil belajar Teknologi

Perkantoran siswa yang memiliki gaya belajar kinestetik.

$\mu_{B 1}=$ Hasil belajar Teknologi

Perkantoran siswa yang memiliki gaya belajar visual.

$\mathrm{A} \times \mathrm{B}=$ Interaksi antara strategi pembelajaran dengan gaya belajar.

\section{HASIL DAN PEMBAHASAN \\ Hasil}

Pengujian hipotesis dilakukan untuk membuktikan kebenaran hipotesis yang telah ditetapkan sehingga diperoleh data apakah hipotesis yang dirancang dalam sebuah penelitian ditolak atau diterima. Untuk keperluan pengujian hipotesis dengan menggunakan teknik analisis varian dua jalur (ANAVA) faktorial 2x2 dan kemudian dilanjutkan dengan uji lanjut dengan menggunakan uji Scheffe maupun uji Tuickey, diperlukan harga rata-rata tiap kelompok perlukan sebagai sumber data penelitian, berikut ini disajikan rangkuman data hasil belajar Teknologi Perkantoran siswa sebagai sumber pengolahan data untuk pengujian hipotesis. Rangkuman data tersebut dapat dilihat pada Tabel 1 dengan menggunakan analisis deskriptif.

Tabel 2. Rangkuman Data Hasil Perhitungan Analisis Deskriptif.

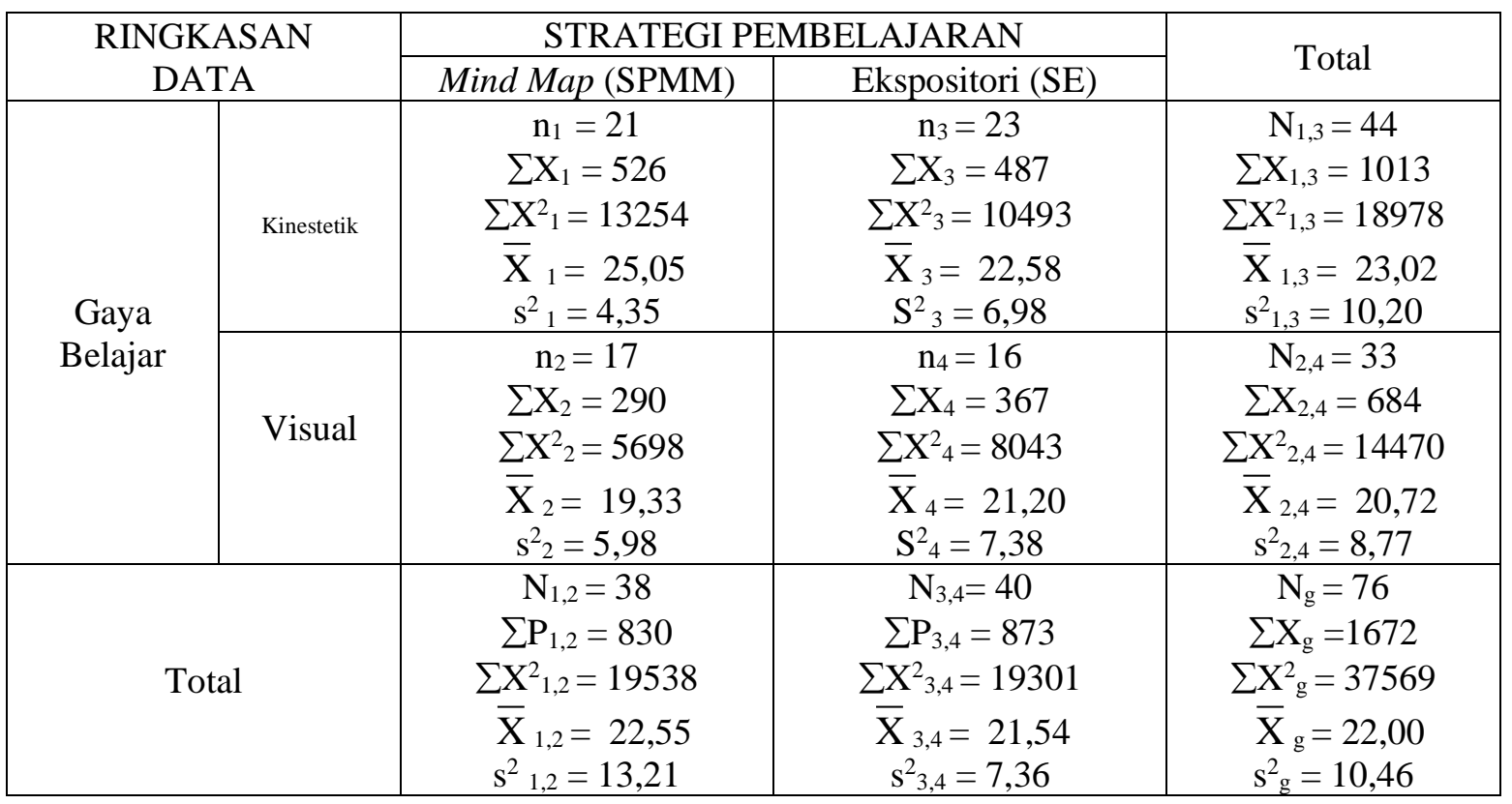


Setelah data tabel 2 diolah dengan ANAVA 2 jalur faktorial 2 × 2, maka diperoleh hasil analisis seperti ditunjukkan pada Tabel 3.

Tabel 3. Ringkasan Perhitungan ANAVA Faktorial 2x2

\begin{tabular}{|l|c|c|c|c|c|c|}
\hline \multicolumn{1}{|c|}{ Sumber Varians } & JK & $\mathbf{d k}$ & $\mathbf{K T}$ & $\mathbf{F}_{\text {hitung }}$ & $\begin{array}{c}\mathbf{F}_{\text {tabel }} \\
(\mathbf{\alpha = 0 , 0 5 )}\end{array}$ & Ket. \\
\hline Strategi & 37.48 & 1 & 37.48 & 5.72 & & Signifikan \\
Gaya Belajar & 34.03 & 1 & 34.03 & 5.19 & 3,97 & Signifikan \\
Interaksi & 241.8 & 1 & 241.8 & 36.91 & & Signifikan \\
\hline Dalam kelompok (galat) & 313.31 & 72 & 5.74 & & & \\
Total & 678.4 & 75 & & & & \\
\hline
\end{tabular}

Pada tabel ringkasan ANAVA untuk strategi pembelajaran diperoleh $\mathrm{F}_{\text {hitung }}=5,72>$ $\mathrm{F}_{\text {tabel }}=3,97$, untuk gaya belajar $\mathrm{F}_{\text {hitung }}=5,19>$ $\mathrm{F}_{\text {tabel }}=3,97$ dan untuk interaksi diperoleh $\mathrm{F}_{\text {hitung }}$ $=36,91>\mathrm{F}_{\text {tabel }}=3,97$ berdasarkan data-data tersebut, dapat disimpulkan adanya interaksi antara strategi pembelajaran dengan gaya belajar yang mempengaruhi hasil belajar Teknologi Perkantoran siswa.

\section{Perbedaan Hasil Belajar Teknologi Perkantoran Antara Siswa yang Diajar dengan Strategi Mind Map dan Strategi Pembelajaran Ekspositori}

Pengujian dilakukan terhadap hipotesis statistik yang dirumuskan sebagai berikut:

$$
\begin{aligned}
& H o: \mu_{P_{12}} \leq \mu_{P_{34}} \quad ; \\
& H a: \mu_{P_{12}}>\mu_{P_{34}}
\end{aligned}
$$

Pernyataan hipotesis tersebut adalah :

Ho = Tidak terdapat perbedaan hasil belajar Teknologi Perkantoran antara siswa yang diajar dengan strategi Mind Map dengan siswa yang diajar dengan strategi pembelajaran Ekspositori

$\mathrm{Ha}=$ Siswa yang diajar dengan strategi Mind Map memperoleh hasil belajar Teknologi Perkantoran lebih tinggi daripada siswa yang diajar dengan strategi pembelajaran ekspositori.

Dari hasil perhitungan analisis tentang perbedaan hasil belajar Teknologi Perkantoran siswa yang diajar dengan strategi Mind Map sebesar $\overline{\mathrm{X}}=22,55$ dan strategi pembelajaran ekspositori $\overline{\mathrm{X}}=21,54$, didapat hasil perhitungan $F_{h}$ sebesar 5,72 dan harga tabel $F_{t}$ adalah 3,97. Dengan demikian temuan penelitian menyimpulkan, bahwa hipotesis penelitian yang menyatakan: hasil belajar Teknologi Perkantoran siswa yang diajar dengan strategi Mind Map lebih tinggi daripada hasil belajar Teknologi Perkantoran siswa yang diajar dengan strategi pembelajaran ekspositori pada taraf kepercayaan $\alpha=0,05$ telah teruji kebenarannya.

Perbedaan Hasil Belajar Teknologi Perkantoran Antara Siswa dengan Gaya Belajar Kinestetik dan Gaya Belajar Visual.

Pengujian dilakukan terhadap hipotesis statistik yang dirumuskan sebagai berikut:

$$
\text { Ho: } \mu_{P_{13}} \leq \mu_{P_{24}} \quad ; \quad H a: \mu_{P_{13}}>\mu_{P_{24}}
$$

Pernyataan hipotesis tersebut adalah :

$\mathrm{H}_{0}=$ Tidak Terdapat perbedaan hasil belajar Teknologi Perkantoran antara siswa yang memiliki gaya belajar kinestetik dengan siswa yang memiliki gaya belajar visual

Ha = Hasil belajar Teknologi Perkantoran siswa yang memiliki gaya belajar kinestetik lebih tinggi daripada hasil belajar Teknologi Perkantoran siswa yang memiliki gaya belajar visual

Hasil perhitungan analisis varian tentang perbedaan hasil belajar Teknologi Perkantoran antara siswa yang memiliki gaya belajar kinestetik dan gaya belajar visual dengan rata-rata $\bar{X}=23,02$ dan $\bar{X}=20,72$. Berdasarkan Tabel 3 dapat dihitung $\mathrm{F}_{\mathrm{h}}=5,19$ dan harga tabel untuk $\alpha=0,05$ dengan $\mathrm{dk}$ (1) diperoleh $F_{t}=3,97$ sehingga dapat dinyatakan $F_{h}(5,19)>F_{t}(3,97)$. Dengan demikian temuan penelitian menyimpulkan hipotesis penelitian yang menyatakan: hasil belajar Teknologi Perkantoran siswa yang memiliki gaya belajar kinestetik lebih tinggi daripada hasil belajar siswa yang memiliki gaya belajar visual pada 
taraf kepercayaan $\alpha=0,05$ telah teruji kebenarannya.

\section{Interaksi Antara Strategi Pembelajaran dan Gaya Belajar Terhadap Hasil Belajar Teknologi Perkantoran Siswa}

Pengujian dilakukan terhadap

hipotesis statistik yang dirumuskan sebagai berikut :

$$
\text { Ho : Interaksi }(\mathrm{B} \times \mathrm{T})=0 \quad \text {; }
$$

\section{$\mathrm{Ha}:$ In}

Pernyataan hipotesis tersebut adalah :

Ho = Tidak terdapat interaksi antara strategi pembelajaran dan gaya belajar terhadap hasil belajar Teknologi Perkantoran siswa.

$\mathrm{Ha}=$ Terdapat interaksi antara strategi pembelajaran dan gaya belajar terhadap hasil belajar Teknologi Perkantoran siswa.

Berdasarkan hasil perhitungan ANAVA faktorial $2 \times 2$ diperoleh hasil perhitungan $\mathrm{F}_{\mathrm{h}}=$ 36,91 dengan harga tabel $F_{t}$ untuk taraf kepercayaan $(\alpha)$ sebesar 0,05 dengan $\mathrm{dk}=1$ adalah $F_{t}=3,97$ sehingga dapat dinyatakan $F_{h}$ $(26,71)>F_{t}(3,97)$, dengan demikian dapat disimpulkan pernyataan hipotesis penelitian yang menyatakan: terdapat interaksi antara

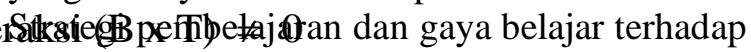
hasil belajar Teknologi Perkantoran siswa telah teruji kebenarannya pada taraf signifikan $\alpha=$ 0,05 .

Data yang diperoleh dalam penelitian ini berasal dari sampel yang jumlahnya berbeda untuk setiap sel Anava. Sehingga perlu dilakukan uji Schefee, hasil pengujian dengan menggunakan uji Scheffee dapat dilihat dalam Tabel 4.

Tabel 4. Ringkasan Hasil Pengujian Dengan Menggunakan Uji Scheffe

\begin{tabular}{|c|c|c|c|c|c|}
\hline \multirow{2}{*}{ No } & \multirow{2}{*}{\multicolumn{2}{|c|}{ Hipotesis Statistik }} & \multirow{2}{*}{$F_{\text {hitung }}$} & \multicolumn{2}{|c|}{$F_{\text {tabel }}$} \\
\hline & & & & $\alpha=5 \%$ & $\alpha=1 \%$ \\
\hline 1 & Ho $: \mu_{1}=\mu_{2}$ & $\mathrm{Ha}: \mu_{1}>\mu_{2}$ & 4,05 & 2,70 & 4,30 \\
\hline 2 & Ho $: \mu_{1}=\mu_{3}$ & $\mathrm{Ha}: \mu_{1}>\mu_{3}$ & 5,13 & 2,70 & 4,30 \\
\hline 3 & Нo $: \mu_{1}=\mu_{4}$ & $\mathrm{Ha}: \mu_{1}>\mu_{4}$ & 2,81 & 2,70 & 4,30 \\
\hline 4 & Ho $: \mu_{2}=\mu_{3}$ & $\mathrm{Ha}: \mu_{2}>\mu_{3}$ & 1,62 & 2,70 & 4,30 \\
\hline 5 & Ho $: \mu_{2}=\mu_{4}$ & $\mathrm{Ha}: \mu_{2}>\mu_{4}$ & 1,05 & 2,70 & 4,30 \\
\hline 6 & Ho $: \mu_{3}=\mu_{4}$ & $\mathrm{Ha}: \mu_{3}>\mu_{4}$ & 4,42 & 2,70 & 4,30 \\
\hline
\end{tabular}

Dari hasil uji Scheffe diperoleh kesimpulan yaitu : (1) rata-rata skor hasil belajar Teknologi Perkantoran siswa yang diajar dengan menggunakan strategi Mind Map yang memiliki gaya belajar kinestetik lebih tinggi daripada siswa yang diajar menggunakan strategi pembelajaran ekspositori yang memiliki gaya belajar kinestetik, (2) rata-rata skor hasil belajar Teknologi Perkantoran siswa yang diajar dengan menggunakan strategi Mind Map yang memiliki gaya belajar kinestetik lebih tinggi dari siswa yang diajar menggunakan strategi pembelajaran ekspositori yang memiliki gaya belajar visual, (3) rata-rata skor hasil belajar Teknologi Perkantoran siswa yang diajar dengan menggunakan strategi Mind Map pada siswa yang memiliki gaya belajar kinestetik lebih tinggi dari pada siswa yang diajar dengan strategi pembelajaran ekspositori dengan gaya belajar kinestetik, (4) rata-rata skor hasil belajar Teknologi Perkantoran siswa yang diajar dengan menggunakan strategi pembelajaran ekspositori pada siswa yang memiliki gaya belajar kinestetik lebih tinggi rendah daripada siswa yang diajar dengan strategi pembelajaran ekspositori dengan gaya belajar visual, (5) rata-rata skor hasil belajar Teknologi Perkantoran siswa yang diajar dengan menggunakan strategi Mind Map pada siswa yang memiliki gaya belajar kinestetik lebih tinggi daripada siswa yang diajar dengan strategi pembelajaran ekspositori dengan gaya belajar visual, (6) rata-rata skor hasil belajar Teknologi Perkantoran siswa yang diajar dengan menggunakan strategi pembelajaran ekspositori pada siswa yang memiliki gaya belajar visual lebih tinggi daripada siswa yang diajar dengan strategi pembelajaran Mind Map dengan gaya belajar visual.

Hasil pengujian hipotesis di atas, menunjukkan adanya interaksi antara strategi pembelajaran dan gaya belajar terhadap hasil belajar Teknologi Perkantoran . Interaksi antara strategi pembelajaran dengan gaya belajar tersebut dapat divisualisasikan dalam bentuk grafis pada gambar 1 . 


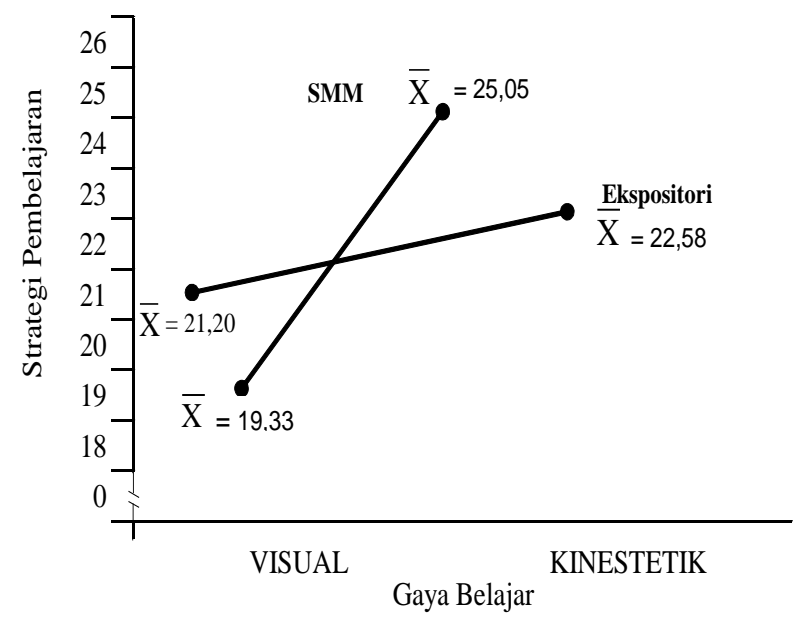

Gambar 1. Interaksi Strategi Pembelajaran dan Gaya Belajar terhadap Hasil Belajar Teknologi Perkantoran .

Berdasarkan hasil pengujian hipotesis ketiga yang menyatakan adanya interaksi antara strategi pembelajaran dengan gaya belajar, maka perlu dilakukan uji perbedaan rata-rata antara dua proporsi. Gambar 1. menunjukkan pengaruh dan interaksi dari strategi pembelajaran dan gaya belajar terhadap hasil belajar Teknologi Perkantoran yang diperoleh siswa, rata-rata hasil belajar Teknologi Perkantoran siswa yang diajar dengan strategi Mind Map lebih tinggi dibandingkan dengan strategi pembelajaran ekspositori. Penelitian ini juga membuktikan faktor gaya belajar sebagai salah satu karakteristik siswa perlu pula diperhatikan karena terbukti bahwa gaya belajar berpengaruh terhadap hasil belajar Teknologi Perkantoran .

\section{Pembahasan Hasil Penelitian}

Dari hasil pengolahan data yang dilakukan terdapat perbedaan hasil belajar Teknologi Perkantoran antara siswa yang diajar dengan strategi Mind Map dengan strategi pembelajaran ekspositori, yaitu rata-rata hasil belajar Teknologi Perkantoran siswa yang diajar dengan strategi Mind Map lebih tinggi daripada rata-rata hasil belajar Teknologi Perkantoran siswa yang diajar dengan Strategi pembelajaran ekspositori. Kenyataan ini membuktikan bahwa strategi Mind Map lebih baik dalam meningkatkan pemahaman siswa daripada penggunaan strategi pembelajaran ekspositori.

Strategi pembelajaran Mind Map merupakan bagian pembelajaran kuantum (Quantum Teaching-Learning) yang berasal dari teori pembelajaran konstruktivisme kognitif dengan menekankan kemampuan siswa untuk membangun sendiri pengetahuan di dalam benaknya dan peran guru bukan hanya sekedar memberikan pengetahuan kepada siswa melainkan memberikan kemudahan belajar (how to learn) pada siswa dengan memberikan kesempatan kepada siswa untuk menemukan atau menerapkan ide-ide mereka sendiri. Pembelajaran kuantum memiliki pandangan tertentu tentang pembelajaran dan pembelajar De Porter, dkk (1999) diantaranya: (1) Pembelajaran berlangsung secara aktif karena pebelajar itu aktif dan kreatif. Bukti keaktifan dan kekreatifan itu dapat ditemukan dalam peranan dan fungsi otak kanan dan otak kiri pembelajar. Pembelajaran pasif mengingkari kenyataan bahwa pembelajar itu aktif dan kreatif, mengingkari peranan dan fungsi otak kanan dan otak kiri. (2) Pembelajaran berlangsung efektif dan optimal bila didasarkan pada karakteristik gaya belajar pembelajar sehingga penting sekali pemahaman atas gaya belajar pembelajar. Setidak-tidaknya ada tiga gaya belajar yang harus diperhitungkan dalam proses pembelajaran, yaitu gaya auditoris, gaya visual, dan gaya kinestetis (3) Pembelajaran terutama pengajaran membutuhkan keserasian konteks dan isi. Segala konteks pembelajaran perlu dikembangkan secara serasi dengan isi pembelajaran. Untuk itulah harus diciptakan dan dipelihara suasana yang memberdayakan atau menggairahkan, landasan yang kukuh, lingkungan fisikal-mental yang mendukung, dan rancangan pembelajaran yang dinamis. Selain itu, perlu juga diciptakan dan dipelihara penyajian yang prima, pemfasilitasan yang lentur, keterampilan belajar yang merangsang 
untuk belajar, dan keterampilan hidup yang suportif.

Hasil penelitian menunjukkan bahwa rata-rata hasil belajar Teknologi Perkantoran siswa yang memiliki gaya belajar kinestetik lebih tinggi daripada hasil belajar Teknologi Perkantoran siswa yang memiliki gaya belajar visual. Selanjutnya dalam penelitian ini juga terbukti bahwa hasil belajar Teknologi Perkantoran siswa yang memiliki gaya belajar kinestetik yang diajar dengan Strategi pembelajaran Mind Map lebih tinggi daripada hasil belajar Teknologi Perkantoran siswa yang diajar dengan Strategi pembelajaran ekspositori. Hal ini mengindikasikan bahwa siswa yang mempunyai gaya belajar kinestetik lebih mampu memahami bahan pelajaran Teknologi Perkantoran denagn cara Mind Map dibandingkan siswa yang mempunyai gaya belajar visual. Penelitian ini juga membuktikan bahwa siswa yang memiliki gaya belajar kinestetik lebih cocok diajar dengan menggunakan Strategi Mind Map. Pembelajaran dengan Strategi Mind Map sangat tepat dibandingkan Strategi pembelajaran ekspositori untuk diterapkan pada siswa yang memiliki gaya belajar kinestetik.

Temuan penelitian menunjukkan bahwa terdapat interaksi antara Strategi pembelajaran dan gaya belajar terhadap hasil belajar Teknologi Perkantoran siswa. Siswa yang memiliki gaya belajar kinestetik yang diajar dengan Strategi Mind Map lebih tinggi hasil belajar menggambar tekniknya daripada siswa yang memiliki gaya belajar visual yang diajar dengan Strategi Mind Map. Demikian pula siswa yang memiliki gaya belajar sekuensial abstrak yang diajar dengan Strategi pembelajaran ekspositori memperoleh hasil belajar Teknologi Perkantoran yang lebih tinggi daripada siswa yang memiliki gaya belajar kinestetik dengan Strategi pembelajaran ekspositori. Hal ini mengindikasikan adanya interaksi antara Strategi pembelajaran dengan gaya belajar terhadap hasil belajar Teknologi Perkantoran siswa.

Mind merupakan gagasan berbagai imajinasi. Mind merupakan suatu keadaan yang timbul bila otak (brain) hidup da sedang bekerja (Bahaudin, 1999: 53). Lebih lanjut Bobbi de Porter dan Hernacki (1995: 152) menjelaskan, peta pikiran merupakan teknik pemanfaatan keseluruhan otak dengan menggunakan citra visual dan prasarana grafis lainnya untuk membentuk suatu kesan yang lebih dalam. Peta pikiran adalah teknik meringkas bahan yang dipelajari dan memproyeksikan masalah yang dihadapi ke dalam bentuk peta atau teknik grafik lebih mudah memahaminya (Sugiarto, 2004:75).

Pemetaan pikiran merupakan teknik visualisasi verbal ke dalam gambar. Peta pikiran sangat bermanfaat untuk memahami materi, terutama materi yang diberikan secara verbal. Peta pikiran bertujuan membuat materi pelajaran terpola secara visual dan grafis yang akhirnya membantu merekam, memnperkuat, dan mengingat kembali informasi yang telah dipelajari (Jensen, 2002: 95).

Pada gaya belajar kinestetik, strategi belajar dengan pembuatan peta pikiran akan menjadi hal yang menantang dan menyenangkan untuk dicoba. Gaya belajar kinestetik yang cenderunga aktif, akan menjadikan kegiatan belajar yang melibatkan panca indra mereka khusunya tangan dan imajinasi secara seimbang. Hal ini sangat sesuai dengan kepribadian siswa dengan gaya belajar kinestetik. Sehingga dapat disimpulkan Hasil belajar Teknologi Perkantoran siswa yang diajar dengan menggunakan strategi Mind Map yang memiliki gaya belajar kinestetik lebih tinggi daripada siswa yang diajar menggunakan strategi pembelajaran Mind Map yang memiliki gaya belajar visual.

Sesuai konsep di atas, bagi siswa yang memiliki gaya belajar kinestetik yang diajar dengan menggunakan strategi pembelajaran Mind Map dengan mudah menghubungkan materi pelajaran yang diterimanya dengan kehidupan nyata menjadikannya lebih efektif jika dibandingkan dengan gaya belajar visual karena secara keseluruhan aspek kognitif, psikomotorik, dan afektif terlibat secara langsung dalam proses pembelajarannya.

Sedangkan untuk strategi Mind Map yang menuntut keterlibatan siswa secara mandiri dalam proses belajar, akan menimbulkan kesulitan tersendiri bagi siswa dengan gaya belajar visual. Hal ini disebabkan karena mereka terbiasa pasif dan menerima begitu saja apa yang diberikan oleh gurunya. Mereka akan kesulitan menghubungkan materi pelajaran yang diterima dengan cara membuat rangkuman peta pikiran sacara pribadi dengan mengembangkan kreatifitas mereka. Sehingga Hasil belajar Teknologi Perkantoran siswa yang diajar dengan menggunakan strategi ekspositori yang memiliki gaya belajar visual lebih tinggi daripada siswa yang diajar menggunakan 
strategi pembelajaran Mind Map yang memiliki gaya belajar visual.

\section{PENUTUP}

Berdasarkan hasil penelitian dan pembahasan yang dikemukakan sebelumnya, maka dapat simpulkan bahwa :

1. Hasil belajar Teknologi Perkantoran siswa yang diajarkan dengan Strategi Mind Map lebih tinggi dibandingkan dengan hasil belajar Teknologi Perkantoran siswa yang diajarkan dengan Strategi pembelajaran ekspositori.

2. Hasil belajar Teknologi Perkantoran siswa yang memiliki gaya berpikir sekuensial konkrit lebih tinggi daripada siswa yang memiliki gaya berpikir sekuensial abstrak.

3. Terdapat interaksi antara Strategi pembelajaran dan gaya berpikir yang memberikan perbedaan pengaruh terhadap hasil belajar Teknologi Perkantoran siswa. Perbedaan pengaruh tersebut adalah: (1) Hasil belajar Teknologi Perkantoran siswa dengan gaya berpikir sekuensial konkrit yang diajar dengan Strategi Mind Map lebih tinggi daripada hasil belajar siswa dengan Strategi pembelajaran ekspositori; (2) Hasil belajar Teknologi Perkantoran siswa dengan gaya berpikir sekuensial konkrit yang diajar dengan Strategi Mind Map lebih tinggi daripada hasil belajar siswa dengan gaya berpikir sekuensial abstrak yang diajar dengan Strategi pembelajaran ekspositori; (3) Hasil belajar Teknologi Perkantoran siswa dengan gaya berpikir sekuensial konkrit yang diajar dengan Strategi pembelajaran ekspositori lebih rendah daripada hasil belajar siswa dengan gaya berpikir sekuensial abstrak yang diajar dengan Strategi pembelajaran ekspositori; (4) Hasil belajar Teknologi Perkantoran siswa dengan gaya berpikir sekuensial abstrak yang diajar dengan Strategi Mind Map lebih rendah daripada hasil belajar siswa dengan gaya berpikir sekuensial abstrak yang diajar dengan Strategi pembelajaran ekspositori; (5) Hasil belajar Teknologi Perkantoran siswa yang diajar dengan Strategi Mind Map lebih tinggi daripada hasil belajar siswa yang diajar dengan Strategi pembelajaran ekspositori; (6) Hasil belajar Teknologi Perkantoran siswa dengan gaya berpikir sekuensial konkrit lebih tinggi daripada hasil belajar siswa dengan kemampuan gaya berpikir sekuensial abstrak.

\section{DAFTAR PUSTAKA}

Achmadi. (1993). Islam Sebagai Paradigma Ilmu Pendidikan, Yogyakarta: Aditya Media.

Bahaudin. Taufik. (1999). Brainware Management: Generasi Kelima Manajemen Manusia. Elex Media Komputindo: Jakarta.

DePorter, B, Dkk .(2007). Quantum Teaching. Bandung : Penerbit Kaifa.

DePorter, Bobbi dan Hernacki, Mike. (2013). Quantum Learning: Membiasakan Belajar Nyaman dan Menyenangkan. Bandung: Kaifa Learning.

Djamarah, Syaiful B, \& Zain, Aswan, (2002). Strategi Belajar Mengajar, Jakarta: Rineka Cipta.

Gagne. Robert M, (1989). Kondisi Belajar dan Teori Pembelajaran. (terjemah Munandir). Jakarta: PAU Dirjen Dikti Depdikbud.

Jensen, Eric. (2008). Brain Based Learning. Yogyakarta: Pustaka Pelajar.

Olivia, Femi. (2008). Gembira Belajar dengan Mind Mapping. Jakarta : Gramedia

Porter. De Bobbi dan Hernacki. (2009). Quantum Learning: Membiasakan Belajar Nyaman dan Menyenangkan. Bandung: Kaifa

Sanjaya, W. (2009). Strategi Pembelajaran Berorientasi Standar Proses Pendidikan. Jakarta : Kencana Prenada Media Group

Sanjaya, Wina. (2009). Strategi Pembelajaran Berorientasi Standar Proses Pendidikan. Jakarta: Kencana Prenada Media.

Slameto.( 2003). Belajar dan Faktor- Faktor yang Mempengaruhinya. Rineka Cipta. Jakarta.

Sugiarto, Iwan. (2004). Mengoptimalkan Daya Kerja Otak dengan Berfikir Holistik dan Kreatif. Jakarta: Gramedia Pustaka Utama.

Susanto, Ahmad. (2015). Teori Belajar dan Pembelajaran di Sekolah Dasar. Jakarta: Prenada Media Group.

Tirtarahardja, Umar \& La Sulo. (2005). Pengantar Pendidikan. Jakarta: PT Rineka Cipta. 